\title{
Penetration and Integration of Maritime Consciousness and Moral Education in Colleges*
}

\author{
Xin Dong \\ Zhuhai College of Jilin University \\ Zhuhai, China 519041
}

\begin{abstract}
When the world's main maritime states strengthen marine policy, Chinese marine security faces severe challenge, so China brings maritime security strategy in national strategy. Attentions paid to marine national defense and people's weak maritime consciousness form sharp contrast. Moral education course involved the cultivation of maritime consciousness is one of the forms to train people's maritime consciousness. Strengthening college students' maritime consciousness is an important way to strengthen maritime consciousness of the whole nation. Therefore, moral education on college students must be strengthened. In teaching practice, after-class study and propaganda, we must integrate maritime consciousness and moral education, in order to strengthen the awareness of national defense security, contribute to the implementation of maritime power strategy and then realize the great rejuvenation of Chinese nation.
\end{abstract}

Keywords-maritime consciousness; moral education; penetration and integration

\section{INTRODUCTION}

Subject of Chinese marine culture is state power and all Chinese citizens in all ages, namely all members in Chinese nation. China is a great power with "integration" of inland and ocean. Naturally, "ocean" cannot and has never been ignored by China. China and Chinese culture won't be sound if there is no ocean in Chinese territory and national consciousness. The development of ocean conforms to the process that the relation between human and ocean transforms from "harmony to conflict to harmony". Changes of situation between countries determine changes of state politics, and it changes with constant changes of international maritime situation. National security education, patriotism and socialism honor concept dominate the domestic situation. Therefore, we must integrate maritime consciousness education in moral education system of college students, in order to actuate the reform of ideological and political education in colleges.

*[Fund project] 2014 Guangdong province young creative talent project (humanities and social sciences) Penetration and Integration of Maritime Consciousness and Moral Education (project number: 2014WQNCX188).

\section{IMPORTANCE TO DEEPEN AND DEVELOP MARITIME CONSCIOUSNESS EDUCATION}

A. The Implementation of Maritime Power Strategy Needs to Deepen and Develop Maritime Consciousness Education and Integrate It with Moral Education

In today's world, marine situation changes tremendously. The pursuit of maritime rights has become the center in maritime geopolitical strategy. The security of Chinese sea area is threatened by countries with ulterior motives and the contradiction is increasingly conspicuous. Under this international background, maritime consciousness education has become important project in contemporary theoretical circle of Chinese education. Maritime consciousness refers to people's cognition to take measures in marine environment for survival and development. Maritime consciousness mainly contains marine territory, marine resources and its utilization, marine competition and marine security. In practice, maritime consciousness education and moral education are important contents to improve integrated quality of all the people.

Colleges are important place for knowledge transmission, cultural inheritance, thought innovation and talent cultivation as well as strengthening of maritime consciousness. At present, the primary task of college educators is to establish and improve theoretical system of maritime consciousness education and integrate maritime consciousness and ideological education. However, the investigation results of previous years indicate college students in China have weak maritime consciousness. Therefore, colleges must integrate the strengthening of college students' maritime consciousness in moral education, intensify the penetration and integration of maritime consciousness and moral education in colleges, and strengthen college students' maritime consciousness through moral education course, in order to guarantee the implementation of maritime power strategy.

\section{B. The Improvement of College Students' Quality-Oriented} Education Needs the Penetration and Integration of Maritime Consciousness Education and Moral Education

Education is the foundation to train talents and develop science and technology. Deepening educational reform needs comprehensive quality-oriented education. Colleges are important for talent training, and college students' quality determines national development and Chinese modernization 
construction. Influenced by Chinese traditional culture for a long time, Chinese people generally have weak maritime consciousness, including college students. Our country attaches importance to maritime consciousness education and roundly boosts quality-oriented education.

When Chinese maritime rights and interests and marine security are challenged and threatened, we must combine maritime consciousness education with moral education, in order to improve college students' comprehensive quality and train more technical and management talents with maritime consciousness and scientific and correct thoughts.

\section{Integrate Maritime Consciousness Education in the Moral Education System for College Students to Improve Teachers' Comprehensive Quality and Actuate Moral Education Reform}

Education is inseparable from the support of teaching theory, especially teachers' guidance on students. Therefore, teachers' quality has tremendous influence on students' quality. Theoretical research on maritime consciousness education depends on scientific research departments at all levels and colleges. Roundly improving quality of teachers and training high quality education talents, especially teachers of ideological education is the important basis and premise to integrate maritime consciousness education with moral education.

Maritime consciousness education becomes important subject of national strategic development. Researchers and college teachers are encouraged and supported to research it. Some colleges "related to ocean" have compiled suitable textbooks, researching marine culture, maritime consciousness and ideological and political theory and doing association study on theories. It has distinctly importance significance on establishing and improving theoretical system of maritime consciousness education and improving level of moral education in colleges.

\section{Integration of Moral Education Course and Cultivation of} Maritime Consciousness Is One of the Forms of Education Activity Related to Maritime Consciousness and Effective Way to Strengthen National Defense Consciousness and Chinese Marine Security

Maritime power strategy is the top choice to realize national interest. The great rejuvenation of the Chinese nation cannot do without the realization of maritime power. However, maritime consciousness of Chinese people is restricted by traditional agricultural culture. The consciousness of "attaching importance to land instead of ocean" restricts the development of maritime consciousness and Chinese nation. Currently, few people undertake marine career. Theories about cultivation and development of maritime consciousness are absent. In order to improve people's maritime consciousness, education activities must be organized. The integration of ideological and political education in colleges with the cultivation of maritime consciousness meets needs of education activities related to maritime consciousness and becomes effective form to diversify the activities.
Without the guidance of advanced marine theory, marine practice will become water without a source, and maritime consciousness will only become superficial. Guiding thought of marine theory accepted by most people will appear through integration of maritime consciousness with ideological and political education. With the development of marine career in China, people's maritime consciousness has awakened. However, compared with developed maritime states, our country provides inadequate propaganda and education related to maritime consciousness. It is imperative to rapidly awaken people, especially college students' maritime consciousness, because moral education is effective way to improve college students' national defense consciousness and strengthen Chinese marine security.

\section{ANALYSIS ON REASONS FOR WEAK MARITIME CONSCIOUSNESS OF CHINESE COLLEGE STUDENTS}

First, people are deeply influenced by traditional Chinese "yellow civilization", and marine education fails to strongly support marine culture and science. Few people undertake marine career, including government officials, scientific researchers, technicians and industrial personnel and maritime armed forces that aim at ocean development and utilization directly or indirectly. They deliver advanced marine concept to others and are carrier of modern maritime consciousness. The subject of ocean and marine career is people. Weak maritime consciousness of students cannot promote development of basic education. Especially in recent years, the main carrier of marine geographical course is not marine course in colleges, and inadequate attentions are paid to educators and students. Besides, students seldom contact it and know few about earthly environment. In China, because people think China have "vast territory and abundant resources", the proposition of "prosper marine career" is easily ignored.

Second, marine theory is absent. Theory guides practice. Without advanced marine theory, marine practice will be the most fundamental perceptual knowledge. Under the guidance of advanced marine theory, ocean will develop deeply and reasonably, and advanced maritime consciousness will be accepted by most of the people. The Influence of Maritime Rights on History 1660 - 1783 published in 1890 in America is called "Discussion on Maritime Rights" and written by Mahan, American naval strategist and naval officer. It is praised as "Valuable Book of Navy", having enormous effect on development of American navy. This book is important theoretical basis to promote the second leap of human's maritime consciousness.

Third, education and propaganda of maritime consciousness are weak. In recent years, with the introduction of marine strategy, media publicize the strengthening of maritime consciousness. Although it takes effect, it resembles routine publicity of government on some policy and the effect is not ideal because of narrow scope and superficial contents of propaganda. Chinese marine education fails to keep up with the development of marine career. Excellent people are inseparable from excellent education. People with strong maritime consciousness depend on prominent marine education. The development of marine education is seriously restricted by traditional concept, deficient educational 
resources, absence of educational theory and unsound educational contents. Chinese people have weak maritime consciousness, so strengthening people's maritime consciousness is the premise to realize sustainable development of China.

\section{PENETRATION AND INTEGRATION OF MARITIME CONSCIOUSNESS EDUCATION AND MORAL EDUCATION}

\section{A. Do Theoretical Research on Maritime Consciousness and Explore Ways to Integrate Moral Education with Maritime Consciousness Education}

The improvement of college students' marine consciousness must be supported by theories. Refer to the experience of maritime power, do theoretical research on maritime consciousness and explore ways for penetration and integration of moral education and maritime consciousness education, in order to strengthen college students' maritime consciousness and improve the effectiveness of maritime consciousness education, deliver talents to marine career and achieve the goal of maritime power strategy. Moral education in colleges can serve as the main channel to improve college students' maritime consciousness. Comprehensively improving the level of moral education in colleges admits of no delay and needs qualified teachers.

\section{B. Rebuild the System of Maritime Consciousness Education in College in Contemporary Era}

First, consciousness education must center on marine territory, maritime sovereignty, marine resource, marine security and marine power. Strict management system must be established to avoid chaotic marine education system. Second, establish explicit educational objectives. The objective of maritime consciousness education is to improve maritime consciousness of college teachers and students, train talents with maritime consciousness and related technique, actuate the development of maritime career and promote security of coast defense. At the meantime, adjust teaching objectives according to requirements of educational theories and students' characteristics. Related departments must construct the system of maritime consciousness education. Except for competent administrative departments for education and colleges, the government must train students' maritime consciousness, introduce policies to guide and support the establishment of related system. Units and individuals involved in the research project should analyze on the basis of full investigation, bring the improvement of college students' maritime consciousness in theoretical research and education system, teaching plan, arrangement and implementation of ideological and political course, at the meantime, explore, establish and continuously improve the system of college students' maritime consciousness and establish correct and scientific teaching mechanism.

\section{Enrich the Forms of Moral Education in Colleges and Innovate in the Ways to Train Maritime Consciousness}

In order to improve students' maritime consciousness, varied education activities must be carried out. In moral education, teachers must reasonably design educational contents correctly according to college students' situation in real life and characteristics of ideological activities. In teaching methods and skills, diversified forms must be adopted according to college students' characteristics and make maritime consciousness education effective. In order to improve college students' maritime consciousness, moral education is far from adequate. Culture exhibition and films related to marine knowledge and history on campus should be provided to attract college students' attention. Meanwhile, improve maritime consciousness of college teachers and students through opening training course and visiting museum; take advantage of network, media and public resources in propaganda, organize colorful activities to popularize marine knowledge, establish internet forum to exchange information about marine science and technology, marine security and resources, and establish platform to answer related questions, in order to guide college students to establish maritime consciousness.

\section{CONCLUSION}

The overall objective of maritime consciousness education is to roundly improve maritime consciousness of college teachers and students, train talents with maritime consciousness and related technique, actuate the development of maritime career and promote security of coast defense. Except for competent administrative departments for education and colleges, the government must train students' maritime consciousness, introduce policies to guide and support the establishment of related system and bring the improvement of college students' maritime consciousness in theoretical research and education system, teaching plan, arrangement and implementation of ideological and political course, at the meantime, explore, establish and continuously improve the system of college students' maritime consciousness and establish correct and scientific teaching mechanism.

\section{REFERENCES}

[1] Shao Yongling. Maritime Strategies of Warring States [M], Beijing: Petroleum Industry Press, 2010

[2] Wu Qinglin. Thinking on College Students' Maritime Consciousness and Education [J], Theoretical Observation, 2010(2)

[3] Li Jinming. Strengthen College Students' Maritime Consciousness in Patriotism Education [J], Theoretical Front in Higher Education, 1997, (10): 32-33

[4] Zhang Furong. Exploration on Training College Students' Maritime Consciousness through Ideological and Political Theory Course, Journal of Sichuan Engineering Technical College, 2013(2)

[5] Dong Lili. Research Overview on Domestic Maritime Consciousness [A], Annual Conference of the Chinese Sociology Society and the 2nd Chinese Marine Sociology Forum-Collected Papers of Marine Social Management and Cultural Construction, 2011(7)

[6] Chen Hongyan. The Key to Development of Marine Culture Is Maritime Consciousness Education [J], Maritime Education Research, 2010 (4)

[7] Guo Yuan, Chen Guangzheng. Strengthen Maritime Consciousness Education on College Students through Courses [J], Education and Examination, 2009(3)

[8] Geng Wenqiang. Discussion on Absence of Maritime Consciousness Education in New Course [J], Education and Management, 2010(4) 
[9] La Quanheng. Exploration on Education of College Students' Maritime Consciousness [J], Journal of the Northwest Adult Education, 2013 (2)

[10] Wang Xingang, Chang Xu, Yang Fei. Function of Ideological and Political Class in Strengthening College Students' Maritime Consciousness [J], Youth Literator, 2011 (12)

[11] Sun Jie. Education on Cultivating "Maritime Consciousness" in Ideological and Political Class and the Strategies [J], Journal of Moral Education for Primary and Secondary School, 2013 (4)

[12] Jiang Xiumin, Liu Guangyuan. Construction of Education System for College Students' Maritime Consciousness under Strategy of Maritime Power [J], Maritime Education Research, 2013 (2) 